\title{
Л.В. Никифор
}

\section{АНТИБІОТИКОПРОФІЛАКТИКА ПРИ АБДОМІНАЛЬНОМУ РОЗРОДЖЕННІ: СУЧАСНІ ТЕНДЕНЦІЇ, ВІТЧИЗНЯНІ ТА СВІТОВІ ПОГЛЯДИ НА ПРОБЛЕМУ (ОГЛЯД ЛІТЕРАТУРИ)}

Вищий державний навчальний заклад України «Буковинський державний медичний університет», м. Чернівці

Резюме. У статті наведено огляд даних літератури щодо сучасних підходів та тенденцій до проблеми антибіотикопрофілактики при абдомінальному розро-

Відносна безпечність абдомінального кесарева розтину, зумовлена вдосконаленням техніки втручання, використанням сучасного шовного матеріалу та сучасних схем антибіотикопрофілактики, значно вплинула на поширеність даного методу розродження [3, 5].

Все більше лікарів - акушерів-гінекологів віддають перевагу абдомінальному розродженню внаслідок великої кількості судових позовів при ускладненнях природних пологів, що призводить до втрати медичними працівниками кваліфікаційних навичок класичного акушерства $[7,8]$.

Однак, за даними MO3 України, летальність після даної операції у 2009-2013 рр. коливалася в межах від 0,02 до 0,06 на 1000 пологів та значно перевищувала загальну летальність породіль в акушерських стаціонарах країни.

Сьогодні у світі в структурі причин материнської смертності інфекції посідають третє місце, їм належить 15 \% серед усіх випадків, незважаючи на значний прогрес щодо профілактичного та лікувального застосування антибіотиків [6, 16]. Незважаючи на еволюцію антибактеріальних препаратів, вдосконалення схем антибіотикопрофілактики та антибіотикотерапії в акушерський практиці, оптимізацію технік та технологій оперативного розродження, септичні ускладнення залишаються в першій п'ятірці причин материнської смертності в Україні $[6,7,9]$. дженні, розглянуто сучасний стан питання, проблеми та перспективи їх вирішення.

Ключові слова: кесарів розтин, антибіотикопрофілактика, антибіотикотерапія.

Таким чином, відносна безпечність так званих «верхніх пологів», з одного боку, сприяє їх поширенню, тоді як 3 іншого, велика кількість кесаревих розтинів та динамічна зміна видового складу збудників пуерперальної інфекції потребують постійного вдосконалення технології даного виду розродження, у тому числі підходів до антибіотикопрофілактики [7, 8, 14].

Незважаючи на переконливі дані щодо ефективності доопераційної антибіотикотерапії в країнах пострадянського простору системний підхід до антибіотикопрофілактики сформувався тільки кілька років тому з уведенням в дію відповідних клінічних протоколів: Клінічний протокол «Кесарів розтин», затверджений наказом MO3 України від 27.12.2011 № 977; «Федеральные клинические рекомендации «Антибиотикопрофилактика при абдоминальном родоразрешении», утвержденные российским обществом акушеров-гинекологов», $2013[1,2]$. До того часу в акушерських стаціонарах не було чіткої диференціації антибіотикопрофілактики та антибіотикотерапії, препарати призначалися безсистемно, переважно під час або навіть після операції кесарева розтину $[5,9,11]$.

Так, за даними багатоцентрового ретроспективного дослідження, що було виконане на базі 14 клінік 10 міст Росії, до якого увійшли 1213 пацієнток, котрим було проведено абдомінальне

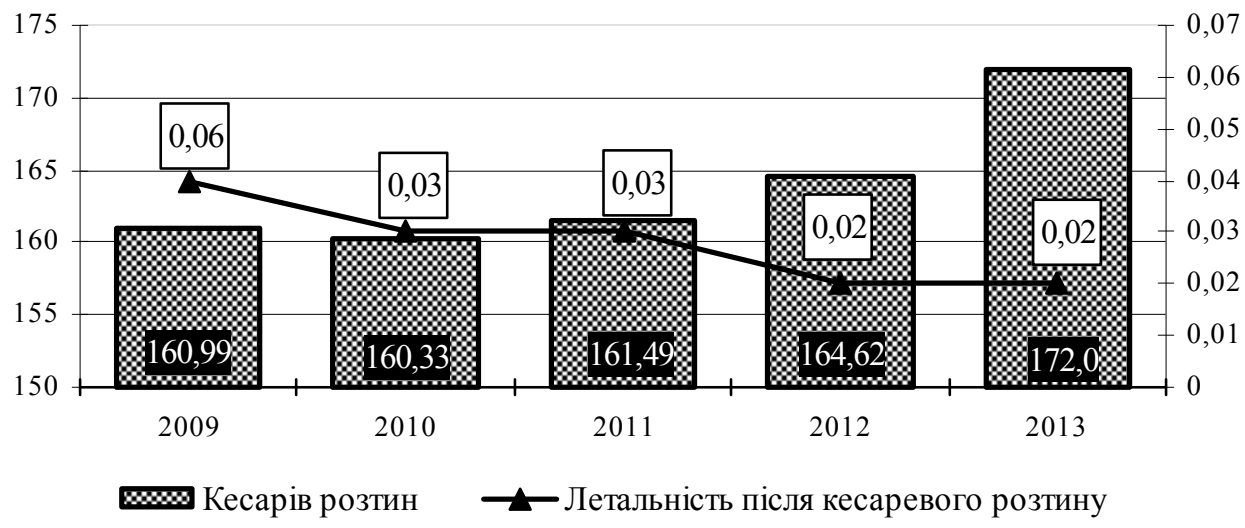

Рис. 1. Динаміка кесаревого розтину та летальності після кесаревого розтину в Україні за 2008-2012 pp. (на 1000 пологів) 
розродження, доопераційна антибіотикопрофілактика в інтервалі від 120 до 30 хвилин після операції проведена тільки в 39,5 \% пацієнток. У значній кількості випадків (30\%) уведення антибіотика проводилося після операції, в інтервалі від 30 хвилин до 24 годин. У 16 \% випадків уведення антибіотика здійснювалося через 24 години після операції. Найнижча кількість септичних ускладнень (2 \%) спостерігалася при введенні антибіотика за 30 хвилин до операції або через 30 хвилин після операції. Також, за даними дослідження, оптимальний вибір препарату для антибіотикопрофілактики (цефалоспорини I-II поколінь, ампіциліни) здійснювався тільки у 51,5 \% [18].

Першою спробою стандартизації підходів до хірургічної антибіотикопрофілактики можна вважати Керівництво з профілактики інфекційних ускладнень у ділянці оперативного втручання (Guideline for Prevention of SurgicalSiteInfection), видане Консультативним комітетом із контролю внутрішньолікарняних інфекцій США (Hospital Infection Control Practices Committee, НІСРАC) у 1999 році. Дане керівництво створене на сучасних засадах доказової медицини та стало основою для подальшого розвитку та вдосконалення схем антибіотикопрофілактики [31].

Згідно з даним погоджувальним документом під хірургічною антимікробною профілактикою (АМП) розуміють дуже короткий курс призначення антимікробного препарату безпосередньо перед початком операції. АМП не є спробою стерилізації, а чітко спланованим заходом, спрямованим на зниження в критичний для пацієнта момент інтраопераційної мікробної контамінації до рівня, що не перевищує можливостей захисних сил його організму. Найчастіше в сучасній хірургії використовують внутрішньовенне введення антибіотиків. Для того, щоб отримати максимальну користь від АМП, необхідно дотримуватися чотирьох основних принципів [31]:

1. АМП необхідно застосовувати для усіх операцій, при яких у клінічних дослідженнях доведена її ефективність (зниження частоти інфекційних ускладнень), а також для операцій, при яких виникнення септичних ускладнень (СУ) призведе до катастрофічних наслідків.

2. Для АМП слід застосовувати безпечні та недорогі препарати, яким притаманна бактерицидна дія проти більшості найбільш імовірних для даної операції контамінуючих організмів.

3. Під час уведення початкової дози антимікробного засобу необхідно забезпечувати досягнення бактерицидної концентрації препарату в сироватці та тканинах до моменту розрізу шкіри.

4. Слід підтримувати терапевтичні рівні концентрації антимікробного препарату в сироватці та тканинах упродовж усієї операції та впродовж перших кількох годин після закриття рани. Оскільки в усіх хірургічних ранах наявна кров, важливою є підтримка терапевтичної дози препарату не тільки у тканинах, а й у сироватці крові [31].

Простим методом визначення показів до антибіотикопрофілактики є врахування класифі- кації хірургічних ран відповідно до ступеня інтраопераційної мікробної контамінації [10]:

I клас («чисті»). До них належать: нетравматичні, неінфіковані хірургічні рани без ознак запалення, які не зачіпають дихального (респіраторного), шлунково-кишкового та статевого трактів, неінфікованих сечовивідних шляхів;

II клас («умовно чисті»). До них належать: рани, які пошкоджують дихальний, шлунковокишковий та сечостатевий тракти за умови відсутності ознак інфекції і порушення правил асептики;

III клас («контаміновані»). До них належать: рани, у яких має місце порушення стерильності під час операції, перфорації органів шлунковокишкового тракту під час операції зі значним витоком його вмісту, є вогнище гострого негнійного запалення;

IV клас («брудні або інфіковані»). До них належать: старі травматичні рани, у яких є нежиттєздатні тканини, та рани 3 наявністю ознак вираженої клінічної форми гнійно-запальної інфекції або 3 перфорацією внутрішніх органів [10].

За визначенням, АМП не показана при операціях, які класифіковані як контаміновані або брудні, до прикладу кесарів розтин при хоріоамніоніті, тривалому безводному періоді, клінічно вузькому тазі тощо. При таких операціях пацієнти, зазвичай, отримують періопераційно антимікробні препарати в режимі терапії [14, 27].

Разом 3 тим ряд авторів вважає, що превентивну антибіотикопрофілактику при кесаревому розтині слід проводити тільки у жінок групи високого ризику розвитку гнійно-септичних ускладнень $[5,17,25]$. Слід зазначити, що така практика прийнятна тільки в пологопомічних закладах 3 облаштуванням операційних блоків, як медично «чистих» приміщень [25].

Найбільш ефективним засобом профілактики пуерперальної інфекції після кесарева розтину $\epsilon$ призначення антибіотиків широкого спектра, в основному бета-лактамних (цефалоспорини 1-2 поколінь, пеніциліни) [11, 19, 27]. Згідно з рекомендаціями ACOG (The American Congress of Obstetricians and Gynecologists) тa SOGC ( The Society of Obstetricians and Gynecologists of Canada) антибіотикопрофілактика має призначатись усім жінкам, яким проводиться кесарів розтин [25, 35, 39].

Цефалоспорини I-II поколінь $є$ найбільш вивченими препаратами для АМП. Ці антибіотики ефективні проти багатьох грампозитивних та грамнегативних бактерій, мають прийнятні фармакокінетичні властивості та помірну вартість. Часто використовується цефазолін, який зазвичай розглядається як препарат вибору для антибіотикопрофілактики при чистих операціях. Цефазолін забезпечує адекватне прикриття багатьох умовно чистих операцій, але при операціях на дистальних відділах кишечнику, при проведенні кесарева розтину, для прикладу, в пологах, коли мали місце численні вагінальні дослідження, для прикриття проти анаеробів слід застосовувати кліндаміцин або метронідазол [19, 20, 30]. 
Для цефалоспоринів, які найчастіше використовуються для АМП, характерна залежність їхньої бактерицидної дії від експозиції. У тих випадках, коли очікувана тривалість операції перевищує час, упродовж якого підтримується терапевтична концентрація введеної дози АМП, слід увести додаткову дозу антибіотика. Для цефазоліну цей інтервал дорівнює 3-4 години.

Визначення часу призначення другої (або третьої та наступних) дози будь-якого препарату АМП оцінюється за трьома критеріями [20]:

- концентрація в тканинах, яка досягається при введенні стандартної терапевтичної дози;

- період напіввиведення даного препарату;

- приблизним значенням мінімальної пригнічуючої концентрації (МПК) для очікуваних збудників СУ $[9,20]$.

Альтернативні схеми антибіотикопрофілактики завжди мають бути розглянуті в пацієнтів 3 алергією на бета-лактами в анамнезі. При нечутливості флори до бета-лактамних антибіотиків зручними є захищені ампіциліни (поєднані з інгібіторами бета-лактамаз) [23]. У ряді досліджень доведений зв'язок призначення амоксиклаву 3 некротичним ентероколітом у новонароджених, що обмежує застосування даного препарату під час вагітності $(29,37)$. Також можливі варіанти використання кліндаміцину з гентаміцином, еритроміцину або ванкоміцину (в останніх випадках при можливій контамінації з вагінальним секретом завжди слід додавати метронідазол) $[14,23]$. Отже, за наявності в пацієнтів алергії на беталактамні антибіотики, призначення цефалоспоринів неприпустиме. Тоді, при ймовірній грампозитивній контамінації використовують ванкоміцин або кліндаміцин $[1,3]$. За необхідності впливу на грамнегативні інфекції використовують азотриєнам [9]. У хірургічній практиці аміноглікозиди для проведення антибіотикопрофілактики практично не використовуються. Разом 3 тим комбінація кліндаміцин + гентаміцин вважається другим золотим стандартом антибіотикопрофілактики та антибіотикотерапії в акушерстві [14, 27].

У червні 2004 року опубліковані Рекомендації Робочої групи 3 розробки керівництв щодо запобігання хірургічній інфекції (Surgical Infection Prevention GuidelinesWriters Workgroup), які базуються на критичному аналізі усіх раніше опублікованих керівництв [22]. Основними положеннями, які представляє дане керівництво, $\epsilon$ наступні:

- інфузія антибактеріального препарату починається за 60 хвилин до операційного розрізу;

- антибіотикопрофілактика не триває більше 24 годин після операції;

- у випадку використання цефалоспоринів необхідно виключити наявність алергічних реакцій на бета-лактамні антибіотики в анамнезі. Однак, за наявності алергії в анамнезі можуть бути використані внутрішньошкірні проби та інші методи діагностики;
- дози антибактеріальних препаратів повинні базуватися на даних про масу тіла або індекс маси тіла (IMT) пацієнта. Повторна доза вводиться при тривалості операції, яка у два рази перевищує період напівведення препарату;

- при абдомінальній або вагінальній гістеректомії препаратом вибору є цефотетан, альтернативні антибіотики - цефазолін або цефакситин. При алергії на бета-лактамні антибіотики рекомендовані для застосування кліндаміцин з гентаміцином або ципрофлоксацин [22].

Для того, щоб АМП була практичною та ефективною в кожному лікувальному закладі необхідно розробляти власні прості протоколи, які визначають вибір препарату, час його введення та розподіл обов'язків при проведенні АМП. Для раціонального проведення АМП повинна діяти ефективна програма епідеміологічного та мікробіологічного моніторингу, спрямована на виявлення типових збудників СУ та їх чутливості до антимікробних препаратів у кожному окремому стаціонарі $[3,18,19]$. Методологія проведення такого моніторингу в акушерських стаціонарах стандартизована на засадах доказової медицини наступними документами:наказ МОЗ України від 10.05.2007 № 234 " Про організацію профілактики внутрішньолікарняних інфекцій в акушерських стаціонарах", наказ МО3 України від 04.04.2012 № 236 "Про організацію контролю та профілактики післяопераційних гнійнозапальних інфекцій, спричинених мікроорганізмами, резистентними до дії антимікробних препаратів" [10, 13].

Слід враховувати, що ендометрит після кесарева розтину має полімікробну етіологію. За чисельними даними U.urealyticum також відіграє роль у його патофізіології $[21,26]$.

В Алабамському університеті (м. Бірмінгем, США) було проведене рандомізоване порівняльне подвійне сліпе плацебо-контрольоване дослідження двох режимів антибіотикопрофілактики при кесаревому розтині, метою якого було з'ясування питання - чи знижує розширена антибіотикопрофілактика (активна до U.urealyticum) частоту післяопераційного ендометриту. У дослідженні взяли участь 597 жінок. 3 них 301 пацієнтка після перетиснення пуповини отримала 2 г цефотетану в сполученні з 100 мг доксицикліну, а потім - 1 г азитроміцину через 6-12 годин після розродження. Друга група (296 жінок) отримала 2 г цефотетену у сполученні з плацебо. За результатами дослідження, антибіотикопрофілактика 3 розширеним спектром активності при кесаревому розтині знижує тривалість госпіталізації та частоту післяпологового ендометриту та ранової інфекції [21].

Подальша систематизація результатів наукових досліджень щодо антибіотикопрофілактикики кесарева розтину була здійснена в кокрановському огляді «Антибіотикопрофілактика при кесаревому розтині» [30]. У результаті аналізу великої кількості рандомізованих досліджень доведе- 
но, що АМП при абдомінальному розродженні суттєво знижує ризик СУ, а саме післяпологову лихоманку, ендометрит, ранову інфекцію, інфекції сечовидільних шляхів, кількість тяжких післяопераційних ускладнень. Відзначалося також незначне зниження тривалості перебування хворих у стаціонарі. Незалежно від схеми АП, від відмінностей між групами населення, які увійшли до дослідження, протекторний ефект профілактичної антибіотикотерапії спостерігався у всіх пацієнток, яким проводили КР 3 антибіотикопрофілактикою [30].

Другий кокранівський огляд, який назвався «Схеми антибіотикопрофілактики для кесарева розтину» [35] ставив за мету визначити найбільш доцільну схему антибіотикопрофілактики. Це дослідження виявило, що ампіциліни та цефалоспорини першого покоління виявляють подібну ефективність та немає сенсу використовувати інші препарати більш широкого спектра, або комбіновані схеми АП.

Результати даного дослідження можуть бути застосовані в країнах з обмеженим ресурсом, особливо там, де частота кесаревого розтину висока. Хоча кокранівський огляд включає більше 10 досліджень із країн, що розвиваються, окремо ці дані, на жаль, не аналізувались. Навіть $з$ урахуванням деяких складностей та відмінностей в діагностичних критеріях, несприятлива соціально-економічна ситуація, анемія, втрати крові, кількості вагінальних досліджень, тривалість безводного періоду до початку пологової діяльності можуть посилити протекторний ефект профілактичної антибіотикотерапії [35].

Результати чисельних досліджень дозволяють рекомендувати профілактичну антибіотикотерапію в усіх випадках проведення кесарева розтину. Сдиним виключенням можуть бути операції в закладах охорони здоров'я 3 вкрай низьким рівнем СУ, особливо у випадку наявності системи централізованої подачі газів та облаштування операційних за принципом медично «чистих» приміщень [15, 17, 33].

Як зазначено вище, для жінок з алергією на бета-лактамні антибіотики рекомендований для застосування кліндаміцин. Автори вищенаведених кокранівських оглядів [30,35] рекомендували включити дані рекомендації на рівні міністерств в уніфіковані клінічні протоколи. Відзначена подальша необхідність досліджень, які довели би ефективність певних схем антибіотиків при передчасному вилитті навколоплідних вод, наявності вагінальної та цервікальної інфекції в анамнезі, дисбіотичних станах вагіни та зазначена необхідність проведення аналізу ефективності витрат у порівнянні з витратами у випадку виникнення пуерперальної інфекції [24, 32, 36, 38]. Можливо припустити, що альтернативні схеми антибіотикопрофілактики будуть більш ефективними у вагітних та роділь із дисбіозом вагіни, наявністю під час вагітності деяких вагінальних та цервікальних інфекцій (хламідіоз, мікоплазме- ні ураження). Цей напрямок потребує подальшого вивчення в клініко-експериментальних дослідженнях [23].

Встановлено, що доопераційне призначення антибіотиків скорочує випадки виникнення ендометриту, загальну кількість інфекційних ускладнень у матері, порівняно з уведенням антибіотика після перерізання пуповини. У ряді досліджень доведено, що така доопераційна антибіотикопрофілактика не пов'язана зі зростанням числа інфекцій у новонароджених або селекцією резистентних бактерій, які викликають неонатальний сепсис $[28,34]$.

Передумовою та, відповідно, предиктором розвитку серйозних інфекційних ускладнень у новонароджених, вагітних та породіль $є$ носійство бета-гемолітичного стрептокока, що зумовлює необхідність проведення скринінгових досліджень, допологової санації та призначення антибіотиків під час пологів [32].

Незважаючи на наявність значної доказової бази щодо ефективності доопераційної антибіотикопрофілактики кесарева розтину, вибору препаратів, потребує вивчення ефективність уніфікованих схем антибіотикопрофілактики при абдомінальному розродженні у жінок з дисбіотичними станами вагіни, жінок, що хворіли на секстрансмісивні інфекції [26].

Не встановлено клінічної ефективності схем антибіотикопрофілактики при кесаревому розтині для вагітних з алергіями на бета-лактамні антибіотики, вплив на колонізацію шкірних покривів та слизових оболонок новонароджених [12].

Відсутні чіткі схеми тривалості антибіотикотерапії при ПРПО, за пролонгування перебігу більш, ніж на тиждень. Не вивчено впливу тривалої антибіотикотерапії при ПРПО на плід та стан здоров'я новонародженого [4, 12].

3 огляду на вищенаведене та 3 урахуванням стійкої тенденції до зростання питомої ваги абдомінального розродження в Україні, проблема антибіотикопрофілактики залишається вкрай актуальною.

\section{Література}

1. Баев О.Р. Клинический протокол «Антибиотикопрофилактика при проведении абдоминального родоразрешения (кесарево сечение)» / О.Р.Баев // Акушерство и гинеколог. - 2011. - № 4. - С.15-16.

2. Клінічний протокол з акушерської допомоги «Кесарів розтин» / Наказ Міністра охорони здоров'я України від 27.12.2011 № 977 // Здоров’я України. - 2012. № 3 (54). - C. 47-67.

3. Крамарский В.А. Особенности заживления раны на матке после кесарева сечения у родильниц высокой степени риска гнойно-септических осложнений / В.А. Крамарский, В.Н. Дудакова // Сибир. мед. ж. 2009. - № 2. - С. 46-48.

4. Круть Ю.Я. Аналіз перинатальних результатів у разі недоношеної вагітності, яка ускладнилась передчасним розривом плодових оболонок / Ю.Я. Круть, В.А. Пучков // Здоровье женщины. - 2011. - № 7 (63). - C. 167-169.

5. Лысенко К.А. Дифференцированный подход к профилактике гнойно-воспалительных заболеваний после 
кесарева сечения / К.А. Лысенко // Вестн. перинатол., акуш. и гинекол. - 2006. - № 13. - С.1 88-196.

6. Масивні акушерські кровотечі / [Камінський В.В., Голяновський О.В., Ткаченко Р.О., Чернов А.В.]; за ред. В.В. Камінського. - К.: РВА «Тріумф», 2010. $232 \mathrm{c}$.

7. Мишель Оден. Кесарево сечение: безопасный выход или угроза будущему? / Оден Мишель. - М., 2006. 97 с. - (Международная школа традицинного акушерства).

8. Назаренко Л.Г. Актуальні аспекти вагітності та пологів у жінок 3 кесаревим розтином в анамнезі (Оглядова стаття) / Л.Г.Назаренко, Л.Ю.Дуброва // Здоровье женщины. - 2014. - № 1. - С. 11-14.

9. Негматуллаева М.Н. Клиническая эффективность профилактики септических осложнений после кесарева сечения / М.Н. Негматуллаева // Рос. вестн. акуш.гинекол. -2007. - № 2. - С. 38-39.

10. "Про організацію контролю та профілактики післяопераційних гнійно-запальних інфекцій, спричинених мікроорганізмами, резистентними до дії антимікробних препаратів" / Наказ МОЗ України від 04.04.2012 № 236 [Електронний ресурс]. - Режим доступу: http:// zakon.rada.gov.ua/go/z 0912-12.

11. Неотложные состояния в акушерстве: руководство для врачей / [Серов В.Н., Сухих Г.Т., Баранов И.И. и др.]; под.ред. В.Н.Серова. - М.: ГЭОТАР-Медиа, 2011. 784c. - (библиотека врача-специалиста).

12. Применение антибиотиков при преждевременном разрыве плодного пузыря: Комментарий БРЗ (последняя редакция: 14 июня 2003 г.): [сб. науч. трудов / науч. ред. FestinM.]. - Женева: GNB, 2005. - 284 p. - Библиотека репродуктивного здоровья ВОЗ.

13. «Про організацію профілактики внутрішньолікарняних інфекцій в акушерських стаціонарах» / Наказ MO3 України від 10.05.2007 №234 // Жін. лікар. 2007. - № 3. - С. 52-74.

14. Радзинский В.Е. Руководство к практическим занятиям по акушерству: учебное пособие [для врачей]/ [под ред. В.Е.Радзинского]. - М.: ГЭОТАР-Медиа, 2007. $656 \mathrm{c}$.

15. Сивец Н.Ф. Основные принципы и тактика антибиотикопрофилактики в хирургической практике / Н.Ф. Сивец // Мед. новости. - 2005. - №12. - С. 32-36.

16. Суханова Л.П. Статистика родовспоможения как фактор обеспечения качества акушерской и перинатальной помощи в России /Л.П. Суханова // Социальные аспекты здоровья населения. - 2009. - № 6. - С. 11-16.

17. Сухих Г.Т. Антибиотикопрофилактика при операции кесарево сечение / Г.Т. Сухих // Врач. - 2011. - №1. C. $1-3$.

18. Чилова Р.А. Практика периоперационной антибиотикопрофилактики при операции кесарево сечение в стационарах Российской Федерации / Р.А. Чилова // Клин. микробиол. антимикробной терапии. - 2006. T. 8, №1. -C. 47-53.

19. Шостак В.А. Антибиотикотерапия в акушерстве и гинекологии/ В.А. Шостак // Мед. панорама. - 2006. № 4. - C. 25-29.

20. Administration of cefazolin prior tosk in incisionis superior to cefazolin at cordclamping in preventing postcesarean infectious morbidity: a randomized, controlled trial / S.A. Sullivan, T. Smith, E. Chang [et al.] // Am.J.Obstet.Gynecol. - 2007. - Vol. 196. - P. 333.

21. Andrews W.W. Randomized clinical trial of extended spectrum antibiotic prophylaxis with coverage for Ureaplasma urealyticum to reduce post-cesarean delivery endometritis / W.W. Andrews // ObstetricsandGynecology. - 2003. - Vol. 101, № 6. - P. 1183-1189.

22. Bratzler D. W. For the Surgical Infection Prevention Guidelines Writers Workgroup. Antimicrobial Prophylaxis for Surgery: An Advisory Statement from the National Surgical Infection Prevention Project /
D.W. Bratzler, P.M. Houck // Clin. Infect. Dis. - 2004. Vol. 38, № 3. - P. 1706-1715.

23. Cecatti J.G. Антибиотикопрофилактика при кесаревом сечении: Комментарий БРЗ (последняя редакция: 18 января 2005 г.) / J.G. Cесаtti. - Женева: Всемирная организация здравоохранения, 2005. - 196 с. Библиотека репродуктивного здоровья ВОЗ.

24. Committee opinion no.465: antimicrobial prophylaxis for cesarean delivery: timing of administration // Obstet. Gynecol. - 2010. - Vol. 116, № 3. - P.791-792.

25. Controversies in OB/GYN: Should patients undergoing low-risk $\mathrm{C} / \mathrm{S}$ receive antibiotic prophylaxis? / A. Kim, K. Boggess, D. Chelmow [et al.] // Contemporary OB/ GYN. - 2006. - № 1. - P. 521-522.

26. Costantine M.M. Timing of perioperative antibiotics for cesarean delivery: a metaanalysis / M.M. Costantine // Am. J.Obstet. Gynecol. - 2008. - №199. - P. 301-306.

27. Current debate on the use of antibiotic prophylaxis for caesarean section/ R.F. Lamont, J.D. Sobel, J.P. Kusanovic [et al.] // BJOG. - 2011. - Vol. 118, № 2. -P.193-201.

28. Elk Grove V. Obstetric and medical complications / Grove V.Elk. -American Academy of Pediatrics and American College of Obstetricians and Gynecologists. In: American Academy of Pediatrics and American College of Obstetricians and Gynecologists, 2008. - 344 p. (Guidelines for perinatal care; 6th ed).

29. Festin M. Применение антибиотиков при преждевременном разрыве плодного пузыря: Комментарий БРЗ (последняя редакция: 14 июня 2003 г.) / M. Festin. Женева: Всемирная организация здравоохранения, 2003. - 176 с. - Библиотека репродуктивного здоровья BO3.

30. Hopkins L. Antibiotic prophylaxis regimens and drugs for cesarean section [Electronic resource]]: Cochrane Database of Systematic Review/ L. Hopkins, F. Smaill. - 2007. - Issue 4,Art.No.: CD001136.DOI: 10.1002/14651858., CD001136. - Назва з титул. Екрану.

31. Hospital Infection Control Practices Advisory Committee. Guideline for prevention of surgical site infection, 1999. Hospital Infection Control Practices Advisory Committee / A.J. Mangram, T.C. Horan, M.L. Pearson [et al.] // Infect Control Hosp Epidemiol. - 1999 Apr. Vol. 20, № 4. - P. 250-280.

32. Ohlsson Arne. Intrapartum antibiotics for known maternal Group B streptococcal colonization (Review) [Electronic resource]]: The Cochrane Collaboration / Arne Ohlsson,Vibhuti Shah. - Published by John Willey \& Sons.2014. - P.4: DOI: 10.1002/14651858.CD007467.pub.4. Режим доступу до журн.

33. Risk factors for surgical site infection after low transverse cesarean section / M.A. Olsen, A.M. Butler, D.M. Willers [et al.] // Infect. Control. Hosp. Epidemiol. - 2008. Vol. 29, № 6. - P. 477-484.

34. Single dose prophylaxis in obstetrics and gynaecologycal surgeries / I. Sadique, S. Abid, S. Aleem [et al.] // Annals. -2009 . - Vol. 15, № 4. - P. 176-179.

35. Smaill F.M. Antibiotic prophylaxis versus no prophylaxis for preventing infection after cesarean section [Electronic resource]]: The Cochrane Collaboration / F.M. Smaill, G.M. Gyte//Cochrane Database Syst Rev.-2012. - № 1 . - CD007482. - Режим доступу до журн.:http:// www.ncbi.nlm.nih.gov/pubmed/20091635.

36. Timing of prophylactic antibiotic admin-istration in the uninfected laboring gravida: a randomized clinical trial / B.D. Thigpen, W.A. Hood, S. Chauhan[et al.] // Am. J. Obstet. Gynecol. - 2005. - Vol. 192. - P.1864-1871.

37. Tita A.N.T. Evolving concepts in antibiotic prophylaxis for cesarean delivery: A systematic review/ A.N.T. Tita, D.J. Rouse, S. Blackwel // Obstet. Gynecol. -2009. - Vol. 113, № 3. - P.675-682.

38. Use of antibiotics for the treatment of preterm parturition and prevention of neonatal morbidity: a metaanalysis / 
C.E.Hutzal, E.M. Boyle, S.L. Kenyon [et al.] // Am. J. Obstet. Gynecol. - 2008. - Vol. 199, № 6. - P. 620-628.

39. Van Schalkwyk J. Antibiotic prophylaxis in obstetric procedures / J. Van Schalkwyk, N. Van Eyk,
M.H. Yudin // J. Obstet. Gynecol. Can. - 2010. - Vol. 32, № 1. - P. 879-885.

\section{АНТИБИОТИКОПРОФИЛАКТИКА ПРИ АБДОМИНАЛЬНОМ РОДОРАЗЕШЕНИИ: СОВРЕМЕННЫЕ ТЕНДЕНЦИИ, ОТЕЧЕСТВЕННЫЕ И МИРОВЫЕ ВЗГЛЯДЫ НА ПРОБЛЕММУ (ОБЗОР ЛИТЕРАТУРЫ)}

\section{Л.В. Никифор}

Резюме. В статье приведены литературные данные о современных подходах и тенденциях антибиотикопрофилактики при абдоминальном родоразрешении, рассмотрено современное состояние вопроса, проблемы и перспективы их решения.

Ключевые слова: кесарево сечение, антибиотикопрофилактика, антибиотикотерапия.

\section{ANTIBIOTIC PROPHYLAXIS IN ABDOMINAL DELIVERY: UP-TO-DATE TRENDS, HOME AND WORLD APPROACHES TO THE PROBLEM (REVIEW OF THE REFERENCES)}

\section{L.V. Nykyfor}

Abstract. The article gives a review of up-to-date approaches and trends to the problem of antibiotic prophylaxis in the abdominal delivery; it considers the current state of the problem, and prospects of its solution.

Key words: cesarean section, antibiotic prophylaxis, antibiotic therapy.

Higher State Educational Institution of Ukraine "Bukovinian State Medical University” (Chernivtsi)

Рецензент - проф. О.В. Кравченко
Buk. Med. Herald. - 2016. - Vol. 20, № 1 (77). - P. 200-205

Надійшла до редакції 29.11.2015 року

( Л.В. Никифор, 2016 